Arab Univ. J. Agric. Sci., Ain Shams Univ., Cairo, Egypt 28(2), 547-562, 2020

Website: http://ajs.journals.ekb.eq

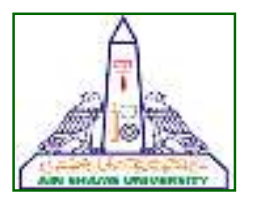

\title{
EFFECT OF SOME EDIBLE COATING AND PACKAGING ON QUALITY ATTRIBUTES OF BROCCOLI FLORETS DURING COLD STORAGE
}

\author{
Neama M. Hussein ${ }^{1^{*}}$, Abdallah ${ }^{2}$ M.M.F., Abou El-Yazied ${ }^{2}$ A. and \\ Rawia E.I. EL-Bassiouny ${ }^{1}$
}

1- Vegetable Handling Dept., Horticulture Research Institute, Agricultural Research Centre, Giza, Egypt

2- Horticulture Dept., Fac. of Agric., Ain Shams Univ., P.O. Box 68, Hadayek Shoubra 11241, Cairo, Egypt

*Corresponding author: neama140@yahoo.com

Received 17 December, 2019

Accepted 10 August, 2020

\section{ABSTRACT}

Broccoli heads (Brassica oleracea var. Italica) Sakura $F_{1}$ Hybrid were get from private farm in alnuwbaria Beheira Government. Heads were harvested at the appropriate stage of harvesting on $22^{\text {th }}$ and $13^{\text {th }}$ February 2017 and 2018 , respectively, and then transported immediately to Horticulture Research Institute, ARC. The impact of edible coatings and packaging on the postharvest appearance and compositional quality changes of separated florets broccoli stored at $0^{\circ} \mathrm{C}$ were determined. Separated florets rinsed with chlorinated water (150 ppm) then washed by distilled water. The samples were then allowed to dry. Broccoli florets were dipped in chitosan solution at 0.5 and $1 \%$ concentration for 3 min. Carboxymethyl cellulose solution at 0.5 and $1 \%$ concentration for 3 min and distilled water represented as control. All treatments were dried and packed in non-perforated polypropylene bags (non$\mathrm{PPPb}$ ) or micro-perforated polypropylene bags (micro-PPPb) and stored at $0^{\circ} \mathrm{C}$ for 20 days plus 2 days at $10^{\circ} \mathrm{C}$ (shelf life). Results showed that loss of weight, decay, off odor, discoloration and peroxidase activity, of broccoli florets were increased as the storage period increased, while general appearance, total chlorophyll and total phenolic content were decreased. For the influence of packaging material the results showed that there were significant differences between packaging materials on quality of florets. Broccoli florets which packed in non-perforated polypropylene bags (non-PPPb) had better florets quality as compared with those packed in micro-perforated polypropylene bags (micro-PPPb) during storage plus shelf life. Chitosan at 0.5 or $1 \%$ is the huge influence in reducing weight loss $\%$, decay (score) peroxidase enzyme activity, off odor (score), discoloration (score) as well as in maintaining total chlorophyll and total phenolic contents during storage plus shelf life. Furthermore, florets dipped in chitosan $1 \%$ and then packed in non$\mathrm{PPPb}$ was the most effective treatment in retarding loss of quality attributes, through the storage periods and helped in retarding deterioration and gave florets with good appearance after 20 days at $0^{\circ} \mathrm{C}$ plus 2 days at $10^{\circ} \mathrm{C}$ (shelf life) without decay.

Keywords: Broccoli florets, Chitosan, Carboxymethyl cellulose, packaging material, cold storage, shelf life.

\section{INTRODUCTION}

Broccoli (Brassica oleracea var. Italica) is a very popular vegetable crop around the world due to its exceptional health benefits and effective in due to anti carcinogenic compound (Gu et al 2015). Besides its appreciable contents of thiamin, riboflavin, niacin, calcium, potassium, magnesium, iron and protein, broccoli is fairly high in vitamin $A$ and $C$ and total phenolic compound (Phuong et al 2018). Broccoli heads senesce rapidly as is typical of commodities harvested before physical growth has ceased Fan and Mattheis, 2000). Broccoli is a perishable commodity with a short shelf life after harvest. Quality losses are mostly due to surface dehydration, degreening and yellowing of sepals accom- 
panied by chlorophyll breakdown, and tissue hardening. Loss of green colour in florets has been attributed to chlorophyll degradation and is related to respiration rate. Ethylene production, and lipid peroxidation processes (Zhuang et al 1995). Cutting process of broccoli florets increase tissue damage and subsequently increase respiration rate and biochemical reactions responsible for changes in color, flavor and texture and causing microbiological contamination (Gonzàlez-Aguilar et al 2009)

Precooling to $0^{\circ} \mathrm{C}$ is enhanced the quality and reducing metabolism and as a result shelf life is prolonged. But the storage quality of fresh-cut broccoli can be further improved by developing new technologies that reduced fresh cut deterioration by delaying decay, softening and color changes. Modified atmosphere packaging with permeable polymeric films enhanced the shelf life of broccoli florets by modification of gases around of products (Schlimme and Rooney, 1994)

The beneficial effect of different packages and polymer films on storage of broccoli florets reported by (Serano et al 2006 and Phuong et al 2018).

Edible coatings are the innovation approaches to maintaining the quality and extend shelf life of product. An edible film has biological materials (proteins, lipids and polysaccharides). The polysaccharides can be included starch and starch derivatives, cellulose derivatives, chitosan, pectin, carboxymethyl cellulose, alginate and other gums (Tzoumaki et al 2009).

Chitosan coating have been successfully used in agricultural and food application, mainly because its antimicrobial and structural properties that allow its use as an edible coating. A chitosan coating have the property to create a semipermeable barrier that controls gas exchange and reduce water loss, thereby maintaining tissue firmness and reducing microbial decay of harvested vegetables for extended periods (Devlieghere, Vermeulen \& Debevere, 2004).

Carboxymethyl cellulose (CMC) is a linear longchain, water-soluble, anionic polysaccharide (Hattori et al 2004). Carboxymethyl cellulose is a cellulose derivative. It has a lot of functions as edible coating for vegetables to retard dehydration, moisture loss, oxygen and carbon dioxide exchanges, decrease respiration, improving textural and seal in volatile flavor compounds (Lee et al 2003), so it can maintain quality during transportation and shelf life of the fresh commodity.
On the other hand, it can be increased demand for fresh-cut broccoli due to its convenience and proved benefits on human health. This study was initiated to evaluate the effect of edible coating (Chitosan and Carboxymethyl cellulose) and packaging on quality parameters of fresh cut broccoli during cold storage plus shelf life.

\section{MATERIALS AND METHODS}

\section{Plant material}

Marketable heads of Sakura $F_{1}$ Hybrid were harvested on $22^{\text {th }}$ and $13^{\text {th }}$ February 2017 and 2018, respectively, from a commercial farm located in Beheira Government. Harvested heads were immediately transferred in refrigerated trucks to Horticulture Research institute, ARC. Heads were separated into florets and rinsed with chlorinated water (150 ppm) then washed by distilled water. The samples were then allowed to dry.

\section{Preparation of coating films}

Chitosan solutions were prepared by dissolving $5 \mathrm{~g}$ or $10 \mathrm{~g}$ chitosan powder in $1000 \mathrm{ml}$ of distilled water, respectively and homogenized by magnetic stirrer ( $5 \mathrm{ml}$ acetic acid) was added into the mixture as a plasticizer (Moreira et al 2011).

Carboxymethyl cellulose solutions were prepared by dissolving $5 \mathrm{~g}$ or $10 \mathrm{~g}$ of Carboxymethyl cellulose (CMC) powder in $1000 \mathrm{ml}$ of water and ethyl alcohol $(2: 1)$ at $75^{\circ} \mathrm{C}$ under the high speed mixer (900 rpm) for $15 \mathrm{~min}$. then, glycerol has been added $(1.5 \% \mathrm{w} / \mathrm{v})$ and the solution was stirred for another 10 min under the same conditions Haffez (2016).

\section{Coating application}

Broccoli florets were dipped in the following filmforming solution for 3 minutes:

1 - Chitosan at $0.5 \%$.

2- Chitosan at $1 \%$.

3- Carboxymethyl cellulose at $0.5 \%$.

4- Carboxymethyl cellulose at $1 \%$.

5- Distilled water (untreated control).

All broccoli florets treatments were dried and sorted for uniformity and packed in micro-perforated polypropylene bags (micro-PPPb) or non-perforated polypropylene bags (non-PPPb) $(30 \mu \mathrm{m}$ thickness, $20 \times 30 \mathrm{~cm}$ size) and each package contained about $250 \mathrm{~g}$ as one replicate. 
Samples were weighted, labeled and stored at refrigerated storage $\left(0^{\circ} \mathrm{C}\right.$ and $90-95 \%$ relative humidity $(\mathrm{RH})$. The cold stored florets samples were examined every 4 days as follows: $4,8,12,16,20$ days of cold storage, after which three randomly selected package of each treatment were transferred for 2 days at $10^{\circ} \mathrm{C}$ (retail storage temperature). This represented a total storage of $6,10,14,18$ and 22 days, respectively.

Three replicates for every treatment were randomly chosen at each evaluating date. The following characters were evaluated for the two seasons before and during storage.

1-Weight loss (\%): It was calculated according to the equation: $=$ [(initial weight of florets - weight of florets at sampling data)/ (initial weight of florets)] x100 (Nath et al 2011).

2- Decay was measured on a scale of $1=$ non , $2=$ slight , $3=$ moderate , $4=$ severe , $5=$ extreme (Risse and Miller, 1986).

3- Off-odor was evaluation on a scale of 1 to 5 where $1=$ none, $2=$ slight, $3=$ moderate, $4=$ severe and $5=$ extremely severe (Saad, 2013).

4- General appearance as evaluated using a scale from 9 to 1 , were $9=$ excellent, $7=$ good, $5=$ fair, $3=$ poor, $1=$ unsalable (Kader et al 1973).

5- Discoloration as evaluated on a scale of 1 to 5 , were $1=$ non, $2=$ slight, $3=$ moderate, $4=$ severe, and $5=$ extra sever, as described by Cantwell et al (2009).

6- Total chlorophyll content as determined according to AOAC (1990).

7- Total Phenolic content as determined according to Singleton et al (1999).

8- Peroxidase enzyme (POD) activity: POD enzyme activity was determined using the method reported by Jiang et al (2002)

\section{Statistical analysis}

Data were analyzed using a completely randomized design factorial (3Factors) with replicates. Two packaging $(P)$ were used as main treatment $\left(1^{\text {st }}\right.$ factor). Each include fife sub treatment $(\mathrm{T})\left(2^{\text {st }}\right.$ factors)[control, chitosan $0.5 \%$, chitosan $1 \%$, CMC $0.5 \%, \mathrm{CMC} 1 \%$ ] and each sub treatment divided to six storage period (S) as sub sub treatment ( $3^{\text {ed }}$ factor) each include three replicates (250 g each). The entire experiment was repeated twice. The data were tabulated and analyzed for statistical significant difference using the LSD test at 0.05 level of significance, according to (SAS. 2006).

\section{RESULTS AND DISCUSSION}

\section{1- Weight loss percentage (\%)}

Data in Table (1) indicated that weight loss \% of broccoli florets was increased gradually as the storage period extended. The highest weight loss values were obtained at the end of the storage. Respiration, senescence and other metabolism processes may be the cause of the loss of weight during storage (Wills et al 1989).

Concerning the effect of packaging data revealed that florets packed in non-perforated polypropylene bags (non-PPPb) had a more striking effect on reducing weight loss as compared with those packed in micro-perforated polypropylene bags (micro PPPb) during storage and shelf life with significant difference between them . These results are in agreement with (Nath et al 2011). Lowest weight loss from broccoli florets packed in non-PPPb is may be due to the confinement of moisture around the produce, which subsequently increases the relative humidity and reduces vapor pressure deficit and transpiration. In addition, packaging in nonPPPb creates a modified atmosphere around the produce which slows down metabolic processes and respiration rate, hence diminished the weight loss during storage (Jacobsson et al 2004).

Data also demonstrate the effect of coating treatments, data showed that all coating treatments gave significantly lower weight loss percentage of florets compared to untreated control, however broccoli florets dipped in chitosan at 0.5 or $1 \%$ were the most effective treatments in reducing the weight loss percentage with significant differences between them followed by caboxymethyl- cellulose (CMC) at $1 \%$, while $\mathrm{CMC}$ at $0.5 \%$ was less effective in this concern. The highest value of weight loss percentage was recorded with untreated control. These results were in agreement with Ansorena et al 2011 for chitosan or CMC.

Lowest weight loss from edible coating treatments has been attributed to the formation of a semipermeable film on the florets surface, consequently modifying the internal atmosphere of the florets with limited gas exchanges due to the coating barrier, thus enzymatic activity and metabolism in evolving respiration can be affected thereby resulting in lower weight loss Raymond et al 2012. Also, Shiri et al 2013 found that edible coating reduced weight loss as it enables epidermal tissues to control water loss and reduce respiration rate, barrier to water vapor reducing moisture loss and delaying product dehydration. 
Table 1. Effect of some edible coating treatments packaging on weight loss $\%$ of Broccoli florets during cold storage (Average of two seasons).

\begin{tabular}{|c|c|c|c|c|c|c|c|c|}
\hline \multirow{2}{*}{$\begin{array}{l}\text { Packaging } \\
\text { (P) }\end{array}$} & \multirow{2}{*}{$\begin{array}{c}\text { Treatment } \\
\text { (T) }\end{array}$} & \multicolumn{6}{|c|}{ Storage $^{\star}$ period(S)(days) } & \multirow[b]{2}{*}{ mean } \\
\hline & & 0 & $4+2$ & $8+2$ & $12+2$ & $16+2$ & $20+2$ & \\
\hline \multirow{6}{*}{ 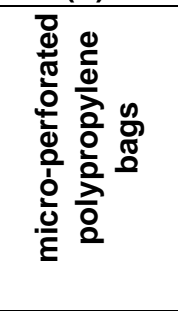 } & Control & 1.25 & 1.56 & 2.53 & 3.83 & 6.76 & 8.78 & 4.12 \\
\hline & chitosan $0.5 \%$ & 0.59 & 1.00 & 1.68 & 1.83 & 2.11 & 3.27 & 1.66 \\
\hline & chitosan $1 \%$ & 0.38 & 0.60 & 0.79 & 1.10 & 1.38 & 2.90 & 1.19 \\
\hline & $\mathrm{CMC}^{\star \star} 0.5 \%$ & 1.01 & 1.47 & 1.89 & 2.65 & 4.32 & 4.32 & 2.17 \\
\hline & $\mathrm{CMC}^{\star *} 1 \%$ & 0.82 & 1.20 & 1.48 & 1.79 & 2.49 & 3.64 & 1.90 \\
\hline & Mean & 0.81 & 1.70 & 1.53 & 2.09 & 3.08 & 4.58 & 2.21 \\
\hline \multirow{6}{*}{ 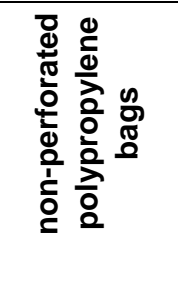 } & Control & 0.62 & 1.02 & 1.46 & 1.76 & 2.28 & 2.96 & 1.67 \\
\hline & chitosan $0.5 \%$ & 0.17 & 0.33 & 0.49 & 0.63 & 0.75 & 0.95 & 0.55 \\
\hline & chitosan $1 \%$ & 0.075 & 0.098 & 0.205 & 0.29 & 0.38 & 0.49 & 0.25 \\
\hline & $\mathrm{CMC}^{\star \star} 0.5 \%$ & 0.35 & 0.71 & 0.94 & 1.11 & 1.39 & 1.77 & 1.05 \\
\hline & $\mathrm{CMC}^{\star *} 1 \%$ & 0.33 & 0.53 & 0.71 & 0.84 & 0.97 & 1.28 & 0.77 \\
\hline & Mean & 0.30 & 0.53 & 0.76 & 0.92 & 1.14 & 1.49 & 0.86 \\
\hline \multirow{6}{*}{ 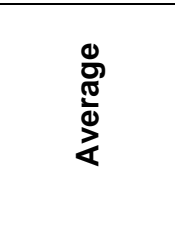 } & Control & 0.93 & 1.29 & 2.00 & 0.68 & 4.47 & 5.87 & 2.89 \\
\hline & chitosan $0.5 \%$ & 0.38 & 0.66 & 0.83 & 1.23 & 1.43 & 2.11 & 1.09 \\
\hline & chitosan $1 \%$ & 0.23 & 0.35 & 0.49 & 0.69 & 0.88 & 1.70 & 0.72 \\
\hline & $\mathrm{CMC}^{\star \star} 0.5 \%$ & 0.68 & 1.09 & 1.32 & 1.50 & 2.03 & 3.05 & 1.61 \\
\hline & CMC** $1 \%$ & 0.57 & 0.86 & 1.09 & 1.32 & 1.73 & 2.46 & 1.34 \\
\hline & Mean & 0.56 & 0.85 & 1.15 & 1.51 & 2.11 & 3.04 & \\
\hline
\end{tabular}

${ }^{*}$ storage period=number of days at $0^{\circ} \mathrm{C}$ days +2 days at $10^{\circ} \mathrm{C}$ (Shelf life)

** Carboxymethyl cellulose LSD at 5\%, $P=0.013, T=0.02, S=0.023, P x T=0.029, S x T=0.051, \quad S x P=0.032, P x S x T=0.073$

The interaction between coating treatments and packaging had a significant effect on weight loss percentage during storage and shelf life. Broccoli florets dipped in chitosan at $1 \%$ and packed in nonPPPb had significantly the lowest value of weight loss $\%$ followed by chitosan at $0.5 \%$ and then packed in non-PPPb with significant differences between them, while the highest value was recorded by uncoated control packed in micro-PPPb.

In general, the interaction among coating treatment, packaging and at the end of storage period was significant. After 20 days at $0^{\circ} \mathrm{C}$ plus 2 days at $10^{\circ} \mathrm{C}$, broccoli florets dipped in chitosan at $1 \%$ and then packed in non-PPPb showed the least weight loss percentage, while untreated control packed in micro-PPPb gave the highest value of weight loss percentage.

\section{2-Deacy}

Data in Table (2) showed that there was significant difference in decay (score) with the prolongation of at the end of storage period, these findings agree with those of Ansorena et al (2011) on broccoli florets. This finding may be due to the continuous chemical and bio-chemical changes happened in fruits such as moisture concentration and transformation of complex compounds to simple forms of more liability to fungal infection such as solid protopectin to the soluble pectin form (Wills et al 1989). Significant difference in decay score were found between non-PPPb and micro-PPPb, however broccoli florets packed in non-PPPb had lower decay in comparison to those packed in micro-PPPb. These results are in agreement with those of Bastrash et al (1993) who found that packaging film alter the gases surrounding a respiring product subsequently slow the normal senescence or decay of the product.

Data revealed that all coating treatments were much better in reducing decay and thus longer storage period were gained. Broccoli florets dipped in chitosan at 1 or $0.5 \%$ were the most effective treatments in minimizing decay incidence during storage plus shelf life with significant difference between them, followed by $\mathrm{CMC}$ at $1 \%$, however $\mathrm{CMC}$ at $0.5 \%$ was less effective in reducing this character. 
The untreated florets (control) showed the highest decay incidence during storage plus shelf life. These results are in accordance with Moreira et al (2011) for chitosan on broccoli florets and Ansorena et al (2011) for chitosan and CMC on broccoli florets.

The favorable effect of chitosan treatments in reducing decay may be due to the chitosan coating, which can inhibit the increase of peroxidase and polyphenol oxidase activity.

Increasing of the antioxidant enzymes and free radical scavenging caused a reduction of physiological deterioration and enhanced resistance of tissue against microbial attacking and reducing the spoilage of the product (Xing et al 2011).

Chitosan films control the decay by modification of atmosphere around the product and by antimicrobial effect of chitosan's positively charged amino group which interacts with negatively charged microbial cell membranes, leading to the leakage of proteinaceous and other intracellular constituents of the microorganisms (Dutta et al 2009).
Durango et al 2006 suggested that chitosan influence of bacteria by the polycationic nature of the molecule, this nature allows to chitosan interacting and forming polyelectrolyte complexes with polymers produced at the bacteria cell surface.

So, edible coatings can modification of atmosphere around the product by internal gas composition which delay ripening, reduce decay, decrease moisture loss, regulation of $\mathrm{O}_{2}, \mathrm{CO}_{2}$, lipids, aroma and flavor compounds Ansorena et al (2011)

The interaction between coating treatments and packaging was significant. However, no decay was observed in broccoli florets dipped in chitosan at $1 \%$ and then packed in non-PPPb.

Also, there was a significant interaction between the coating treatments, packaging and the storage period. For instance the decay started to be shown after 8 days at $0^{\circ} \mathrm{C}$ plus 2 days at $10^{\circ} \mathrm{C}$ for the control treatment, while no decay was observed in florets treated with chitosan at $1 \%$ and then packed in non-PPPb during all storage at the end of storage period. While the micro PPPb treatment was effective up to 16 days at $0^{\circ} \mathrm{C}$ plus 2 days at $10^{\circ} \mathrm{C}$, however, the efficacy of it was reduced afterward.

Table 2. Effect of some edible coating treatments and packaging on Decay (score) of Broccoli florets during cold storage(Average of two seasons)

\begin{tabular}{|c|c|c|c|c|c|c|c|c|}
\hline \multirow{2}{*}{$\begin{array}{l}\text { Packaging } \\
\text { (P) }\end{array}$} & \multirow{2}{*}{$\begin{array}{c}\text { Treatment } \\
(\mathrm{T})\end{array}$} & \multicolumn{6}{|c|}{ Storage $^{*}$ period(S)(days) } & \multirow[b]{2}{*}{ Mean } \\
\hline & & 0 & $4+2$ & $8+2$ & $12+2$ & $16+2$ & $20+2$ & \\
\hline \multirow{6}{*}{ 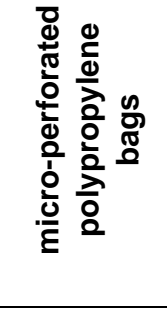 } & Control & 1.00 & 1.00 & 1.66 & 2.33 & 3.66 & 5.00 & 2.44 \\
\hline & chitosan $0.5 \%$ & 1.00 & 1.00 & 1.00 & 1.00 & 1.66 & 2.00 & 1.27 \\
\hline & chitosan $1 \%$ & 1.00 & 1.00 & 1.00 & 1.00 & 1.00 & 1.67 & 1.11 \\
\hline & $\mathrm{CMC}^{\star \star} 0.5 \%$ & 1.00 & 1.00 & 1.33 & 1.66 & 3.00 & 4.00 & 2.00 \\
\hline & $\mathrm{CMC}^{\star *} 1 \%$ & 1.00 & 1.00 & 1.00 & 1.33 & 1.66 & 2.66 & 1.44 \\
\hline & Mean & 1.00 & 1.00 & 1.20 & 1.46 & 2.20 & 3.00 & 1.65 \\
\hline \multirow{6}{*}{ 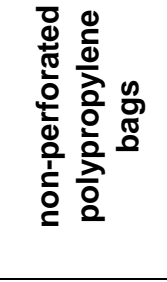 } & Control & 1.00 & 1.00 & 1.33 & 2.00 & 3.66 & 4.66 & 2.27 \\
\hline & chitosan $0.5 \%$ & 1.00 & 1.00 & 1.00 & 1.00 & 1.33 & 1.66 & 1.16 \\
\hline & chitosan $1 \%$ & 1.00 & 1.00 & 1.00 & 1.00 & 1.00 & 1.00 & 1.00 \\
\hline & $\mathrm{CMC}^{\star \star} 0.5 \%$ & 1.00 & 1.00 & 1.00 & 1.33 & 1.66 & 3.00 & 1.50 \\
\hline & $\mathrm{CMC}^{\star \star} 1 \%$ & 1.00 & 1.00 & 1.00 & 1.33 & 1.66 & 2.00 & 1.33 \\
\hline & Mean & 1.00 & 1.00 & 1.06 & 1.33 & 1.86 & 2.46 & 1.45 \\
\hline \multirow{6}{*}{$\begin{array}{l}\frac{0}{\pi} \\
\frac{\pi}{0} \\
\frac{\pi}{\alpha}\end{array}$} & Control & 1.00 & 1.00 & 1.50 & 2.16 & 3.66 & 4.83 & 2.36 \\
\hline & chitosan $0.5 \%$ & 1.00 & 1.00 & 1.00 & 1.00 & 1.50 & 1.83 & 1.22 \\
\hline & chitosan $1 \%$ & 1.00 & 1.00 & 1.00 & 1.00 & 1.00 & 1.16 & 1.06 \\
\hline & $\mathrm{CMC}^{\star \star} 0.5 \%$ & 1.00 & 1.00 & 1.16 & 1.50 & 2.33 & 3.50 & 1.75 \\
\hline & $\mathrm{CMC}^{\star *} 1 \%$ & 1.00 & 1.00 & 1.00 & 1.33 & 1.66 & 2.33 & 1.38 \\
\hline & Mean & 1.00 & 1.00 & 1.13 & 1.40 & 2.03 & 2.77 & \\
\hline
\end{tabular}

*Storage period=number of days at $0^{\circ} \mathrm{C}$ days +2 days at $10^{\circ} \mathrm{C}$ (Shelf life)

** Carboxymethyl cellulose LSD at 5\%, P=0.09, T=0.15, S=0.16, PxT=0.21, SxT=0.36, SxP=0.23, PxSxT=0.52

Decay (score) $1=$ none, $2=$ slight $3=$ moderate, $4=$ severe and $5=$ extreme. 


\section{3- Off odors}

Data in Table (3) indicated that off-odor inside all packages increased considerable and consistently with the prolongation of storage periods. In addition, off-odor inside the different packaging materials started to be observed after 8 days at $0^{\circ} \mathrm{C}$ plus 2 days at $10^{\circ} \mathrm{C}$ (shelf life) and then increased till the end of storage period. These strong off-odor have mainly been associated with sulphur volatile compound, for example, methanethiol, hydrogen sulphide, dimethyl disulphide and dimethyl trisulphide (Forney et al 1991 and Jacobsson et al 2004).
For the effect of packaging data revealed that there were significant difference between packages on off-odor of broccoli florets, however no off-odor of florets packed in micro-perforated polypropylene bags (micro-PPPb) while, those packed in (non$\mathrm{PPPb}$ ) gave slight score of off-odor during storage and shelf life these results coincides with those obtained by Hansen et al (1993) who said that the offodor developed when the package contained a high level of $\mathrm{CO}_{2}$ in combination with very low $\mathrm{O}_{2}$ concentration. Lopez-Galvez et al (1997) found that offodor developed in bags and their score significantly correlated with ethanol and acetaldehyde concentration in the lettuce tissue.

Table 3. Effect of some edible coating treatments packaging on off-odor (score) of Broccoli florets during cold storage (Average of two seasons).

\begin{tabular}{|c|c|c|c|c|c|c|c|c|}
\hline \multirow{2}{*}{$\begin{array}{l}\text { Packaging } \\
\text { (P) }\end{array}$} & \multirow{2}{*}{$\begin{array}{l}\text { Treatment } \\
\text { (T) }\end{array}$} & \multicolumn{6}{|c|}{ Storage $^{*}$ period(S)(days) } & \multirow{2}{*}{ Mean } \\
\hline & & 0 & $4+2$ & $8+2$ & $12+2$ & $16+2$ & $20+2$ & \\
\hline \multirow{6}{*}{ 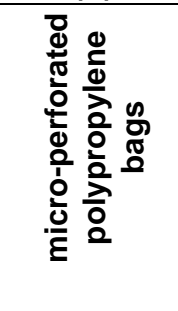 } & Control & 1.00 & 1.00 & 1.00 & 1.00 & 1.00 & 1.00 & 1.00 \\
\hline & chitosan $0.5 \%$ & 1.00 & 1.00 & 1.00 & 1.00 & 1.00 & 1.00 & 1.00 \\
\hline & chitosan $1 \%$ & 1.00 & 1.00 & 1.00 & 1.00 & 1.00 & 1.00 & 1.00 \\
\hline & CMC**0.5\% & 1.00 & 1.00 & 1.00 & 1.00 & 1.00 & 1.00 & 1.00 \\
\hline & $\mathrm{CMC}^{* *} 1 \%$ & 1.00 & 1.00 & 1.00 & 1.00 & 1.00 & 1.00 & 1.00 \\
\hline & Mean & 1.00 & 1.00 & 1.00 & 1.00 & 1.00 & 1.00 & 1.00 \\
\hline \multirow{6}{*}{ 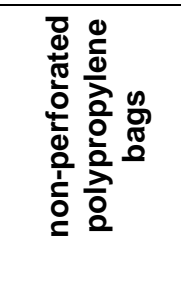 } & Control & 1.00 & 1.00 & 1.33 & 3.33 & 4.33 & 5.00 & 2.66 \\
\hline & chitosan $0.5 \%$ & 1.00 & 1.00 & 1.00 & 1.00 & 1.00 & 1.00 & 1.00 \\
\hline & chitosan $1 \%$ & 1.00 & 1.00 & 1.00 & 1.00 & 1.00 & 1.00 & 1.00 \\
\hline & $C M C^{\star \star} 0.5 \%$ & 1.00 & 1.00 & 1.33 & 2.16 & 2.66 & 3.33 & 1.92 \\
\hline & $\mathrm{CMC}^{\star \star *} 1 \%$ & 1.00 & 1.00 & 1.00 & 1.66 & 2.50 & 3.00 & 1.69 \\
\hline & Mean & 1.00 & 1.00 & 1.13 & 1.83 & 2.30 & 2.66 & 1.65 \\
\hline \multirow{6}{*}{$\begin{array}{l}\frac{0}{\pi} \\
\frac{\pi}{0} \\
\frac{1}{4}\end{array}$} & Control & 1.00 & 1.00 & 1.16 & 2.16 & 2.66 & 3.00 & 1.83 \\
\hline & chitosan $0.5 \%$ & 1.00 & 1.00 & 1.00 & 1.00 & 1.00 & 1.00 & 1.00 \\
\hline & chitosan $1 \%$ & 1.00 & 1.00 & 1.00 & 1.00 & 1.00 & 1.00 & 1.00 \\
\hline & $\mathrm{CMC}^{\star \star} 0.5 \%$ & 1.00 & 1.00 & 1.16 & 1.58 & 1.83 & 2.16 & 1.45 \\
\hline & $\mathrm{CMC}^{\star \star *} 1 \%$ & 1.00 & 1.00 & 1.00 & 1.33 & 1.75 & 2.00 & 1.34 \\
\hline & Mean & 1.00 & 1.00 & 1.00 & 1.42 & 1.65 & 1.83 & \\
\hline
\end{tabular}

* Storage period $=$ number of days at $0^{\circ} \mathrm{C}$ days +2 days at $10^{\circ} \mathrm{C}$ (Shelf life)

** Carboxymethyl cellulose LSD at 5\%, $\mathrm{P}=0.06, \mathrm{~T}=0.10, \mathrm{~S}=0.10, \mathrm{PxT}=0.13, \mathrm{SxT}=0.23, \mathrm{SxP}=0.14, \mathrm{PxS} \times \mathrm{T}=0.32$ off-odor (score) $1=$ none, $2=$ slight, $3=$ moderate, $4=$ severe and $5=$ extremely severe.

Data showed that all coating treatments gave the lowest score of off-odor compared with untreated florets (control) during storage plus shelf life, For instance broccoli florets dipped in chitosan at 0.5 or $1 \%$ was the best treatment, it did not show off-odor during storage plus shelf life as for CMC at $1 \%$, no off-odor was observed till 8 days at $0^{\circ} \mathrm{C}$ plus 2 days at $10^{\circ} \mathrm{C}$.
The interaction between coating treatments and packaging was significant. However, no off-odor was observed in broccoli florets dipped in chitosan at $1 \%$ and then packed in non-PPPb.

In general, the interaction among coating treatments, packaging and at the end of storage period was significant. No off-odor was observed in all coating treatments and untreated control of broccoli 

broccoli florets during cold storage

florets which packed in micro-PPPb and also, chitosan at 0.5 and $1 \%$ and then packed in non-PPPb during all storage periods. While, CMC at 0.5 or $1 \%$ and then packed in non-PPPb gave a slight to moderate score after 18 days of storage plus 2 days at $10^{\circ} \mathrm{C}$, however untreated control packed in (non$\mathrm{PPPb}$ ) gave severe score after the same period.

\section{4- General appearance}

Data shown in Table (4) indicated that, during storage, general appearance of broccoli florets was significantly reduced with time. These results were in agreement with the finding of Ansorena et al (2011) on broccoli florets. Quality (score) was based on fresh appearance, opining, less compact, color change and decay (Forney et al 1991).
Our results revealed that there was significant difference between packaging of broccoli florets during storage plus shelf life. Florets packed in nonperforated polypropylene bags (non-PPPb) showed the highest score of general appearance, while those packed in (micro-PPPb) showed the lowest intensities of these attributes. These results are in agreement with those obtained by Shehata et al (2011) who found that broccoli florets packed in sealed polypropylene bags were perceived to have the highest intensities of freshness, while florets packed in perforated polypropylene bags were perceived to have low intensities of these attributes.

Data also showed that all coating treatments had significant difference between treated and untreated florets (control) in general appearance of broccoli florets during postharvest storage plus shelf

Table 4. Effect of some edible coating treatments packaging on general appearance (score) of Broccoli florets during cold storage (Average of two seasons).

\begin{tabular}{|c|c|c|c|c|c|c|c|c|}
\hline \multirow{2}{*}{$\begin{array}{l}\text { Packaging } \\
\text { (P) }\end{array}$} & \multirow{2}{*}{$\begin{array}{l}\text { Treatment } \\
\text { (T) }\end{array}$} & \multicolumn{6}{|c|}{ Storage $^{\star}$ period (S) (days) } & \multirow[b]{2}{*}{ mean } \\
\hline & & 0 & $4+2$ & $8+2$ & $12+2$ & $16+2$ & $20+2$ & \\
\hline \multirow{6}{*}{ 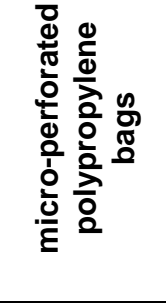 } & Control & 9.00 & 7.66 & 6.33 & 3.00 & 1.67 & 1.00 & 4.78 \\
\hline & chitosan $0.5 \%$ & 9.00 & 9.00 & 7.67 & 6.33 & 4.33 & 3.00 & 6.56 \\
\hline & chitosan $1 \%$ & 9.00 & 9.00 & 8.33 & 7.00 & 6.33 & 4.33 & 7.33 \\
\hline & $\mathrm{CMC}^{\star \star} 0.5 \%$ & 9.00 & 8.33 & 6.33 & 5.00 & 3.00 & 1.66 & 5.56 \\
\hline & $\mathrm{CMC}^{\star *} 1 \%$ & 9.00 & 9.00 & 7.00 & 6.33 & 3.00 & 1.66 & 6.00 \\
\hline & Mean & 9.00 & 8.60 & 7.13 & 5.53 & 3.67 & 2.33 & 6.04 \\
\hline \multirow{6}{*}{ 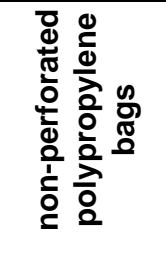 } & Control & 9.00 & 8.33 & 7.00 & 6.33 & 3.66 & 1.66 & 6.00 \\
\hline & chitosan $0.5 \%$ & 9.00 & 9.00 & 9.00 & 7.66 & 7.00 & 5.00 & 7.78 \\
\hline & chitosan $1 \%$ & 9.00 & 9.00 & 9.00 & 9.00 & 8.33 & 7.00 & 8.56 \\
\hline & $\mathrm{CMC}^{\star \star} 0.5 \%$ & 9.00 & 9.00 & 7.66 & 6.33 & 4.33 & 3.00 & 6.56 \\
\hline & CMC ${ }^{* *} 1 \%$ & 9.00 & 9.00 & 8.33 & 7.00 & 6.33 & 4.33 & 7.33 \\
\hline & Mean & 9.00 & 8.87 & 8.20 & 7.27 & 5.93 & 4.20 & 7.24 \\
\hline \multirow{6}{*}{$\begin{array}{l}\frac{0}{\pi} \\
\frac{\pi}{6} \\
\frac{3}{\alpha}\end{array}$} & Control & 9.00 & 8.00 & 6.66 & 4.66 & 2.66 & 1.33 & 5.38 \\
\hline & chitosan $0.5 \%$ & 9.00 & 9.00 & 8.33 & 7.00 & 5.67 & 4.00 & 7.16 \\
\hline & chitosan $1 \%$ & 9.00 & 9.00 & 8.66 & 8.00 & 7.33 & 5.66 & 7.94 \\
\hline & $\mathrm{CMC}^{\star \star} 0.5 \%$ & 9.00 & 8.66 & 7.00 & 5.66 & 3.66 & 2.33 & 6.06 \\
\hline & $\mathrm{CMC}^{\star *} 1 \%$ & 9.00 & 9.00 & 7.66 & 6.66 & 4.66 & 3.00 & 6.67 \\
\hline & Mean & 9.00 & 8.73 & 7.67 & 6.40 & 4.80 & 3.27 & \\
\hline
\end{tabular}

${ }^{*}$ Storage period $=$ number of days at $0^{\circ} \mathrm{C}$ days +2 days at $10^{\circ} \mathrm{C}$ (Shelf life)

** Carboxymethyl cellulose LSD at 5\%, P=0.14, $T=0.22, S=0.24, P x T=0.31, S x T=0.54, \quad S x P=0.34, P x S x T=0.77$

General appearance (score) $9=$ excellent, $7=$ good, $5=$ fair, $3=$ poor and $1=$ unusable. 
life, furthermore, broccoli florets dipped in chitosan at 0.5 or $1 \%$ were the most effective treatments in maintaining general appearance during storage plus shelf life with significant difference between them. In another words, these treatments gave the highest score of appearance, followed by $\mathrm{CMC}$ treatment at $1 \%$, while $\mathrm{CMC}$ at $0.5 \%$ was less effective in this concern. The lowest value of general appearance was recorded with uncoated florets (control).

The maintenance of visual quality by using chitosan or carboxymethyl cellulose may be due to the effect of these treatments on the reduction of weight loss, respiratory activity, degradation by enzymes, microbial rot of fruits and ethylene production (Ansorena et al 2011).

On the other hand, broccoli florets dipped in chitosan at $1 \%$ and then packed in non-PPPb showed the best general appearance.

The interaction among coating treatments, packaging and at the end of storage period had significant effect on general appearance. Florets dipped in chitosan at $1 \%$ and packed in (non-PPPb) showed the best appearance and did not exhibit any changes in their appearance till 18 days at $0^{\circ} \mathrm{C}$ plus 2 days at $10^{\circ} \mathrm{C}$, and gave good appearance at the end of storage period, while chitosan treatment at $0.5 \%$ and then packed in non-PPPb rated good appearance after 16 days at $0^{\circ} \mathrm{C}$ plus 2 days at $10^{\circ} \mathrm{C}$. On the other hand, untreated florets or CMC at $0.5 \%$ or $1 \%$ which packed in micro-PPPb had the worst appearance after 20 days at $0^{\circ} \mathrm{C}$ plus 2 days at $10^{\circ} \mathrm{C}$.

\section{5-Discoloration}

The results in Table (5) revealed that there were increments in discoloration for the cut surface of broccoli florets as period of storage extended. These results coincide with those of Ansorena et al (2011) on broccoli florets. The change of color is related primarily to the oxidation of phenolic compounds to o-quinones by polyphenol oxidase (PPO) presence of oxygen. Quinones can polymerize be to dark brown, black or red polymers.
Moreira et al (2011) found that broccoli florets separated caused increasing in PPO activity which oxidizing the phenolic compounds to browning color.

Concerning the effect of packaging, data revealed that there was significant difference between packaging materials. Non-PPPb prevented the discoloration in the cut surface of broccoli florets and showed the lowest score of discoloration when compared with micro-PPPb which showed the higher score during storage plus shelf life.

All coating treatments reduced the incidence of discoloration compared to untreated florets (control). Dipping florets in chitosan at $(0.5$ or $1 \%)$ prevented discoloration in the cut surface and had lower score of discoloration with no significant difference between them followed by CMC at $1 \%$, $\mathrm{CMC}$ at $0.5 \%$ was less effective in this concern. On the contrary, untreated control showed the highest score in discoloration. These findings agree with those of Ansorena et al (2011) for chitosan and CMC found that broccoli florets coated with chitosan or CMC did not impart significant changes in initial color were effective for inhibition enzymatic browning, obtained good color. These inhibiting of enzymatic browning were related with the prevention of PPO enzyme activity (Vickers et al 2005). So, chitosan or CMC treatments have a preventive effect against any changes that might occur in color (Ansorena et al 2011).

The interaction between coating treatments and packaging was significant. However, Broccoli florets dipped in chitosan at $1 \%$ and then packed in non$\mathrm{PPPb}$ did not show any changes in the color of the cut surface.

Regarding the interaction among coating treatments and packaging and storage period, data revealed that broccoli florets dipped in chitosan at $1 \%$ and then packed in non-PPPb did not show any changes in the cut surface color till 16 days at $0^{\circ} \mathrm{C}$ plus 2 days at $10^{\circ} \mathrm{C}$ and gave non to slight score of discoloration at the end of storage. Moreover, chitosan at $0.5 \%$ and packed in non-PPPb was the second best. However untreated control which packed in non-PPPb or micro-PPPb resulted in severe discoloration with the highest score at the same period. 
Table 5. Effect of some edible coating treatments and packaging on Discoloration (score) of Broccoli florets during cold storage (Average of two seasons)

\begin{tabular}{|c|c|c|c|c|c|c|c|c|}
\hline \multirow{2}{*}{$\begin{array}{l}\text { Packaging } \\
\text { (P) }\end{array}$} & \multirow{2}{*}{$\begin{array}{c}\text { Treatment } \\
\text { (T) }\end{array}$} & \multicolumn{6}{|c|}{ Storage $^{\star}$ period(S)(days) } & \multirow[b]{2}{*}{ Mean } \\
\hline & & 0 & $4+2$ & $8+2$ & $12+2$ & $16+2$ & $20+2$ & \\
\hline \multirow{6}{*}{ 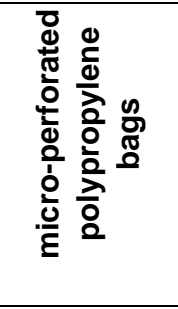 } & Control & 1.33 & 2.67 & 3.67 & 4.67 & 5.00 & 5.00 & 3.72 \\
\hline & chitosan $0.5 \%$ & 1.00 & 1.00 & 1.00 & 1.00 & 2.00 & 2.33 & 1.39 \\
\hline & chitosan $1 \%$ & 1.00 & 1.00 & 1.00 & 1.00 & 1.67 & 2.00 & 1.28 \\
\hline & $\mathrm{CMC}^{\star \star} 0.5 \%$ & 1.00 & 1.33 & 2.00 & 3.33 & 4.33 & 4.67 & 2.78 \\
\hline & $\mathrm{CMC}^{\star \star} 1 \%$ & 1.00 & 1.00 & 1.33 & 2.33 & 3.33 & 4.33 & 2.22 \\
\hline & Mean & 1.07 & 1.40 & 1.80 & 2.47 & 3.27 & 3.67 & 2.28 \\
\hline \multirow{6}{*}{ 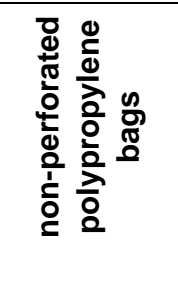 } & Control & 1.00 & 1.67 & 2.67 & 3.67 & 4.33 & 5.00 & 3.06 \\
\hline & chitosan $0.5 \%$ & 1.00 & 1.00 & 1.00 & 1.00 & 1.33 & 1.67 & 1.17 \\
\hline & chitosan $1 \%$ & 1.00 & 1.00 & 1.00 & 1.00 & 1.00 & 1.33 & 1.06 \\
\hline & $\mathrm{CMC}^{\star \star} 0.5 \%$ & 1.00 & 1.00 & 1.67 & 2.67 & 3.00 & 3.33 & 2.11 \\
\hline & $\mathrm{CMC}^{\star *} 1 \%$ & 1.00 & 1.00 & 1.00 & 1.67 & 2.00 & 4.00 & 1.78 \\
\hline & Mean & 1.00 & 1.13 & 1.47 & 2.00 & 2.33 & 3.07 & 1.83 \\
\hline \multirow{6}{*}{ 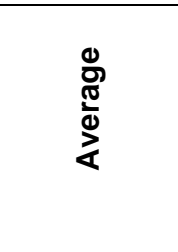 } & Control & 1.17 & 2.17 & 3.17 & 4.17 & 4.67 & 5.00 & 3.39 \\
\hline & chitosan $0.5 \%$ & 1.00 & 1.00 & 1.00 & 1.00 & 1.67 & 2.00 & 1.28 \\
\hline & chitosan 1\% & 1.00 & 1.00 & 1.00 & 1.00 & 1.33 & 1.67 & 1.17 \\
\hline & $\mathrm{CMC}^{\star \star} 0.5 \%$ & 1.00 & 1.17 & 1.83 & 3.00 & 3.67 & 4.00 & 2.44 \\
\hline & $\mathrm{CMC}^{\star *} 1 \%$ & 1.00 & 1.00 & 1.17 & 2.00 & 2.67 & 4.17 & 2.00 \\
\hline & Mean & 1.03 & 1.27 & 1.63 & 2.23 & 2.80 & 3.37 & \\
\hline
\end{tabular}

* Storage period $=$ number of days at $0^{\circ} \mathrm{C}$ days +2 days at $10^{\circ} \mathrm{C}$ (Shelf life)

${ }^{\star *}$ Carboxymethyl cellulose LSD at $5 \%, P=0.19, T=0.30, S=0.33, P x T=0.42, S x T=0.74, \quad S x P=0.46, P x S x T=1.05$

Discoloration was evaluated on a scale of 1 to 5 where $1=$ none, $2=$ slight, $3=$ moderate, $4=$ severe and $5=$ extra severe.

\section{6- Total chlorophyll content}

A statistically significant decrease was noticed in total chlorophyll content with time during storage (Table 6) Ansorene et al (2011) and Kumar \& Singh (2017) came to similar results. This decrement in chlorophyll content could be attributed to gradual increase in destruction by chlorophyll degrading peroxidase activity and also transformation chloroplasts to chromoplasts by chlorophyllase activity (Charles et al 1991).

For the effect of packaging, data show that there was significant difference between packages. Broccoli florets packed in non-perforated polypropylene bags reduced the loss of chlorophyll content as compared with those packaged in (micro-PPPb). These results are in agreement with Kumar and Singh (2017) who found that the increase in chlorophyll content was recorded for non-perforated packages in comparison perforated packages. Holding florets in non-PPPb sealed package resulted in higher levels of $\mathrm{CO}_{2}$ and lower levels of $\mathrm{O}_{2}$ (passive modified atmosphere), which apparently was sufficient to prevent color changes, inhibit certain ripening processes which reduce chlorophyll degradation in broccoli florets (Ansorena et al 2011). Also, these results were in agreement with (Serrano et al 2006) who found that broccoli florets packed in polypropylene maintained total chlorophyll content during storage.

Regarding the effect of coating treatments, data showed that all coating treatments gave significantly the highest value of total chlorophyll content in broccoli florets as compared with untreated florets, for instance, broccoli florets dipped in chitosan at 0.5 or $1 \%$ had significantly the highest value of total chlorophyll contents during cold storage and shelf life, followed by CMC at $1, \%$ while the lowest ones were obtained from untreated florets (control). These results were in agreement with those obtained by Ansorena et al (2011) for chitosan and CMC. 
Table 6. Effect of some edible coating treatments packaging on total chlorophyll $(\mathrm{mg} / 100 \mathrm{~g}$ fresh weight) of Broccoli florets during cold storage (Average of two seasons).

\begin{tabular}{|c|c|c|c|c|c|c|c|c|}
\hline \multirow{2}{*}{$\begin{array}{c}\text { Packaging } \\
\text { (P) }\end{array}$} & \multirow{2}{*}{$\begin{array}{c}\text { Treatment } \\
(\mathrm{T})\end{array}$} & \multicolumn{6}{|c|}{ Storage $^{\star}$ period(S)(days) } & \multirow{2}{*}{ Mean } \\
\hline & & 0 & $4+2$ & $8+2$ & $12+2$ & $16+2$ & $20+2$ & \\
\hline \multirow{6}{*}{ 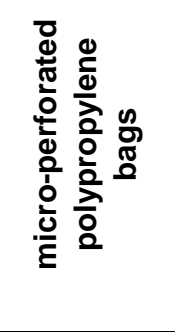 } & Control & 88.30 & 80.13 & 74.32 & 71.12 & 64.32 & 57.67 & 72.60 \\
\hline & chitosan $0.5 \%$ & 88.58 & 86.18 & 83.38 & 79.43 & 73.32 & 69.41 & 80.05 \\
\hline & chitosan $1 \%$ & 89.17 & 87.76 & 85.37 & 81.47 & 77.77 & 72.02 & 82.15 \\
\hline & $\mathrm{CMC}^{\star \star} 0.5 \%$ & 88.25 & 82.40 & 77.25 & 73.45 & 68.40 & 64.65 & 75.73 \\
\hline & $\mathrm{CMC}^{* *} 1 \%$ & 88.42 & 84.33 & 81.53 & 77.29 & 70.48 & 67.05 & 78.18 \\
\hline & Mean & 88.81 & 84.02 & 80.37 & 76.55 & 70.86 & 66.16 & 77.74 \\
\hline \multirow{6}{*}{ 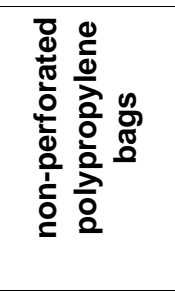 } & Control & 88.30 & 81.48 & 77.28 & 72.28 & 68.28 & 63.81 & 75.24 \\
\hline & chitosan $0.5 \%$ & 88.87 & 86.22 & 83.27 & 80.23 & 76.48 & 73.30 & 81.39 \\
\hline & chitosan $1 \%$ & 89.17 & 87.76 & 86.28 & 83.57 & 79.17 & 76.47 & 83.83 \\
\hline & $\mathrm{CMC}^{\star \star} 0.5 \%$ & 88.44 & 83.65 & 79.35 & 75.45 & 70.55 & 66.35 & 77.30 \\
\hline & $\mathrm{CMC}^{\star *} 1 \%$ & 88.65 & 85.25 & 80.30 & 77.34 & 73.25 & 70.45 & 79.21 \\
\hline & Mean & 88.81 & 84.87 & 81.29 & 77.77 & 73.54 & 70.07 & 79.39 \\
\hline \multirow{6}{*}{ 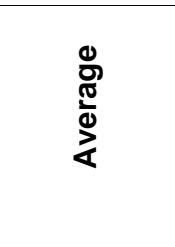 } & Control & 88.16 & 80.81 & 75.80 & 71.70 & 66.30 & 60.74 & 73.92 \\
\hline & chitosan $0.5 \%$ & 88.72 & 86.20 & 83.32 & 79.83 & 74.90 & 71.36 & 80.72 \\
\hline & chitosan $1 \%$ & 89.47 & 87.42 & 85.83 & 82.52 & 78.47 & 74.24 & 83.99 \\
\hline & $\mathrm{CMC}^{\star \star} 0.5 \%$ & 88.35 & 83.02 & 78.30 & 74.45 & 69.47 & 65.50 & 76.51 \\
\hline & $\mathrm{CMC}^{\star *} 1 \%$ & 88.54 & 84.79 & 80.91 & 77.32 & 71.86 & 68.75 & 78.69 \\
\hline & Mean & 88.65 & 84.45 & 80.83 & 77.16 & 72.20 & 68.12 & \\
\hline
\end{tabular}

${ }^{*}$ Storage period $=$ number of days at $0^{\circ} \mathrm{C}$ days +2 days at $10^{\circ} \mathrm{C}$ (Shelf life)

** Carboxymethyl cellulose LSD at 5\%, P=0.25, T=0.38, $\mathrm{S}=0.42, \mathrm{PxT}=0.53, \mathrm{SxT}=0.93, \mathrm{SxP}=0.58, \mathrm{PxSxT}=$ 1.31

Moreover, the obtained results can be explained by the fact reported by (Ansorena et al 2011) who said that the coating films with chitosan or CMC improves green color retention, with the best results obtained with chitosan coating. The films act as a gas barrier reducing the tissue. Oxygen intake can prevent the degradation of green colors.

Also, the reduction of chlorophyll loss of broccoli florets during storage by using chitosan may be attributed to these materials reduced in lower activity of florets, thus lower respiration rate resulted in lower activity of chlorophylls and consequence reduced color changes (Ansorena et al 2011).

The interaction between coating treatments and packaging was significant. However, the highest value of total chlorophyll was observed in broccoli florets dipped in chitosan at $1 \%$ and then packed in non-PPPb. In general, the interaction among coating treatments, packaging and at the end of storage was significant. After 20 days at $0^{\circ} \mathrm{C}$ and 2 days at $10^{\circ} \mathrm{C}$. Broccoli florets dipped in chitosan at 0.5 or $1 \%$ and packed in non-PPPb showed the highest value of total chlorophyll, while untreated florets packed in (micro-PPPb) gave the lowest value of total chlorophyll content.

\section{7-Total Phenolic content}

Results in Table (7) showed that there were significant decreases in phenolic contents of broccoli with prolonged storage for all treatment, these results confirm of Raseetha and Nadirah (2018).

Fruit and vegetables have a lot of enzyme which can be oxidizing and degradation of phenolic compounds and caused by loss integrity of cell membrane. PPO and POD were the main agents responsible for the degradation of phenols in plants (Baltacig et al 2011).

Loss the integrity of the membrane results in the barriers and allowing enzymes to act on their substrate (Zhang et al 2015). The decrease in phenolic content on broccoli florets is probably due to the oxidation of PPO enzyme to give the colored quinones and quinone was oxidized directly by PPO (Queiroz et al 2008). 
Table 7. Effect of some edible coating treatments packaging on total phenolic content (mg GAE / $100 \mathrm{~g}$ fresh weight) of Broccoli florets during cold storage (Average of two seasons).

\begin{tabular}{|c|c|c|c|c|c|c|c|c|}
\hline \multirow{2}{*}{$\begin{array}{l}\text { Packaging } \\
\text { (P) }\end{array}$} & \multirow{2}{*}{$\begin{array}{l}\text { Treatment } \\
\text { (T) }\end{array}$} & \multicolumn{6}{|c|}{ Storage $^{*}$ period(S)(days) } & \multirow{2}{*}{ Mean } \\
\hline & & 0 & $4+2$ & $8+2$ & $12+2$ & $16+2$ & $20+2$ & \\
\hline \multirow{6}{*}{ 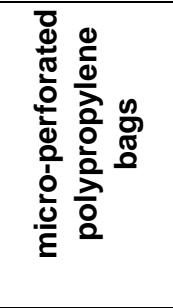 } & Control & 90.85 & 85.67 & 81.94 & 78.85 & 74.54 & 69.70 & 80.26 \\
\hline & chitosan $0.5 \%$ & 92.65 & 90.54 & 88.44 & 87.34 & 83.94 & 81.02 & 87.32 \\
\hline & chitosan $1 \%$ & 93.40 & 91.15 & 89.67 & 88.77 & 87.17 & 86.16 & 89.38 \\
\hline & $\mathrm{CMC}^{\star \star} 0.5 \%$ & 91.66 & 88.14 & 84.51 & 82.35 & 79.68 & 77.15 & 83.91 \\
\hline & $\mathrm{CMC}^{\star *} 1 \%$ & 92.06 & 90.14 & 88.18 & 85.20 & 83.05 & 80.34 & 86.49 \\
\hline & Mean & 92.13 & 89.13 & 86.55 & 84.50 & 81.68 & 78.87 & 85.47 \\
\hline \multirow{6}{*}{ 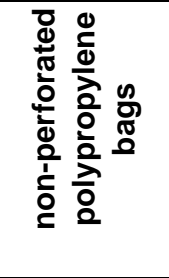 } & Control & 91.82 & 89.14 & 85.23 & 82.95 & 79.93 & 77.00 & 84.35 \\
\hline & chitosan $0.5 \%$ & 93.28 & 92.31 & 90.76 & 89.61 & 88.71 & 87.74 & 90.41 \\
\hline & chitosan $1 \%$ & 94.00 & 93.71 & 93.10 & 92.39 & 92.00 & 91.04 & 92.71 \\
\hline & $\mathrm{CMC}^{\star \star} 0.5 \%$ & 92.42 & 89.77 & 87.58 & 85.70 & 83.84 & 81.68 & 86.83 \\
\hline & $\mathrm{CMC}^{\star *} 1 \%$ & 92.81 & 90.77 & 89.05 & 86.18 & 85.17 & 84.33 & 88.32 \\
\hline & Mean & 92.86 & 91.14 & 89.15 & 87.37 & 85.93 & 84.36 & 88.47 \\
\hline \multirow{6}{*}{ 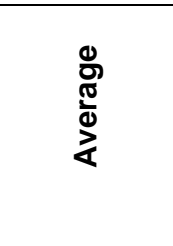 } & Control & 91.33 & 87.41 & 83.58 & 80.90 & 77.24 & 73.36 & 82.31 \\
\hline & chitosan $0.5 \%$ & 92.97 & 91.43 & 89.60 & 88.47 & 86.33 & 84.38 & 88.86 \\
\hline & chitosan $1 \%$ & 93.70 & 92.43 & 91.36 & 90.58 & 89.58 & 88.60 & 91.05 \\
\hline & $\mathrm{CMC}^{\star *} 0.5 \%$ & 92.04 & 88.95 & 86.04 & 84.03 & 81.76 & 79.41 & 85.37 \\
\hline & $\mathrm{CMC}^{\star *} 1 \%$ & 92.43 & 90.46 & 88.63 & 85.69 & 84.12 & 82.34 & 87.28 \\
\hline & Mean & 92.49 & 90.13 & 87.85 & 85.93 & 83.80 & 81.62 & \\
\hline
\end{tabular}

* Storage period=number of days at $0^{\circ} \mathrm{C}$ days +2 days at $10^{\circ} \mathrm{C}$ (Shelf life)

** Carboxymethyl cellulose LSD at 5\%, P=0.55, T=1.24, $S=0.26, P x T=0.34, S x T=0.59, \quad S x P=0.37, P x S x T=0.84$ GAE $=$ Gallic acid

Concerning the effect of packaging, data showed that there were significant difference between packaging on total phenolic content, broccoli florets packed in (non-PPPb) had lower total phenolic content as compared with those packed in (micro-PPPb). These results were in agreement with Serrano et al (2006) who found that polypropylene packages maintained total phenolic content of broccoli florets during storage.

Concerning the effect of coating treatments, data revealed that all coating treatments gave significantly the highest value of total phenolic content as compared with untreated florets (control). Furthermore, broccoli florets dipped in chitosan at 1 or $0.5 \%$ had significantly the highest value of total phenolic content during storage plus shelf life with significant difference between them, followed by CMC at $1 \%$, while the lowest ones were obtained from untreated florets (control). These results were in line with the findings of Ansorena et al (2011) who suggested that these compounds may have reduced respiration rate and its metabolic activities, hence suppressing the enzyme activities during storage.
Chitosan can eliminate reactive oxygen species scavengers, leading to increase phenolic contents and antioxidants (Jongsri et al 2016). Also, chitosan treatments has also been reported to activate the antioxidant enzymes catalase (CAT), superoxide dismutase (SOD) and peroxidase (POD), which consider an important part of the antioxidant potential during storage, in broccoli (Ansorena et al 2011)

The interaction between coating treatments and packaging was significant. Broccoli florets dipped in chitosan at $1 \%$ or $0.5 \%$ and packed in non-PPPb gave the highest value of total phenolic content.

The interaction between coating treatments, packaging and at the end of storage was significant. After 20 days at $0^{\circ} \mathrm{C}$ plus 2 days at $10^{\circ} \mathrm{C}$, broccoli florets dipped in chitosan at $1 \%$ and then packed in (non-PPPb) showed the highest value of total phenolic content, while untreated florets (control) and then packed in (micro-PPPb) gave the lowest ones in this concern. 


\section{8- Peroxidase enzyme activity}

Data in Table (8) indicated that peroxidase (POD) activity of broccoli florets increased along storage period; these results are compatible with Balouchi et al (2011) on broccoli. The increasing of POD activity is caused delaying senescence. Balouchi et al (2011) found that POD enzyme cause catalyzes of corruption $\mathrm{H}_{2} \mathrm{O}_{2}$, this causes senescence of product. So, POD enzyme destroys pigments of chlorophyll and is considered an indication of senescence and intense stress.

Funamoto et al (2002) reported that POD activity increased yellowing of broccoli florets and the lowest POD associated with the lowest chlorophyll content.
Concerning the effect of packaging, data showed that there were significant difference between packaging on peroxidase activity, however, broccoli florets packed in (non-PPPb) had reduced the enzyme activity as compared with (micro$\mathrm{PPPb}$ ) during storage and shelf life.

Concerning the effect of coating treatments, data reveled that all coating treatments gave significantly the lowest active of peroxidase enzyme as compared with untreated florets (control), however broccoli florets dipped in chitosan at 1 or $0.5 \%$ had significantly the lowest active of peroxidase enzyme during storage plus shelf life with significant difference between them, followed by CMC at $1 \%$, while the lowest ones were obtained from untreated florets (control).

Table 8. Effect of some edible coating treatments packaging on peroxidases activity (U/g. fresh weight) of Broccoli florets during cold storage (Average of two seasons).

\begin{tabular}{|c|c|c|c|c|c|c|c|c|}
\hline \multirow{2}{*}{$\begin{array}{l}\text { Packaging } \\
\text { (P) }\end{array}$} & \multirow{2}{*}{$\begin{array}{l}\text { Treatment } \\
\text { (T) }\end{array}$} & \multicolumn{6}{|c|}{ Storage $^{\star}$ period(S)(days) } & \multirow{2}{*}{ Mean } \\
\hline & & 0 & $4+2$ & $8+2$ & $12+2$ & $16+2$ & $20+2$ & \\
\hline \multirow{6}{*}{ 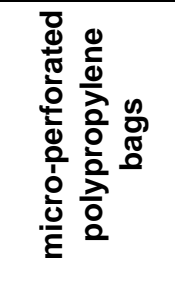 } & Control & 216.30 & 230.60 & 245.55 & 286.70 & 316.90 & 346.30 & 273.72 \\
\hline & chitosan $0.5 \%$ & 203.29 & 214.40 & 220.20 & 238.50 & 248.35 & 260.15 & 230.65 \\
\hline & chitosan $1 \%$ & 196.35 & 202.15 & 207.05 & 225.44 & 238.74 & 245.94 & 219.28 \\
\hline & $\mathrm{CMC}^{\star \star} 0.5 \%$ & 209.85 & 223.55 & 239.55 & 252.75 & 268.75 & 286.54 & 246.83 \\
\hline & $\mathrm{CMC}^{\star \star} 1 \%$ & 207.40 & 219.10 & 230.49 & 242.90 & 354.20 & 271.10 & 237.53 \\
\hline & Mean & 206.64 & 217.67 & 228.56 & 249.26 & 265.39 & 282.01 & 241.60 \\
\hline \multirow{6}{*}{ 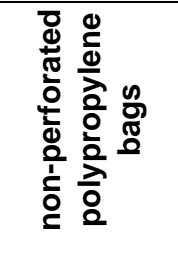 } & Control & 212.35 & 222.35 & 235.54 & 253.25 & 278.35 & 298.45 & 250.05 \\
\hline & chitosan $0.5 \%$ & 196.70 & 208.80 & 218.50 & 226.70 & 232.40 & 238.80 & 220.32 \\
\hline & chitosan $1 \%$ & 188.25 & 196.45 & 203.05 & 208.25 & 212.15 & 219.25 & 204.56 \\
\hline & $\mathrm{CMC}^{\star \star} 0.5 \%$ & 203.00 & 215.54 & 226.40 & 241.70 & 268.75 & 260.70 & 233.30 \\
\hline & $\mathrm{CMC}^{\star \star} 1 \%$ & 199.72 & 210.85 & 221.65 & 230.75 & 242.75 & 251.64 & 226.23 \\
\hline & Mean & 200.01 & 210.80 & 221.03 & 232.13 & 243.63 & 253.77 & 226.89 \\
\hline \multirow{6}{*}{$\begin{array}{l}\frac{D}{\pi} \\
\frac{\pi}{0} \\
\frac{1}{\alpha}\end{array}$} & Control & 214.32 & 226.47 & 240.54 & 269.97 & 297.62 & 322.37 & 261.88 \\
\hline & chitosan $0.5 \%$ & 199.99 & 211.10 & 219.35 & 232.60 & 240.37 & 249.47 & 225.48 \\
\hline & chitosan $1 \%$ & 192.30 & 199.30 & 205.05 & 216.85 & 225.45 & 232.60 & 211.92 \\
\hline & $\mathrm{CMC}^{\star \star} 0.5 \%$ & 206.42 & 219.55 & 232.97 & 247.22 & 260.62 & 273.97 & 240.07 \\
\hline & $\mathrm{CMC}^{\star \star} 1 \%$ & 203.57 & 214.97 & 226.07 & 236.82 & 248.47 & 261.62 & 231.88 \\
\hline & Mean & 203.32 & 214.28 & 224.79 & 240.69 & 254.51 & 267.89 & \\
\hline
\end{tabular}

* Storage period=number of days at $0^{\circ} \mathrm{C}$ days +2 days at $10^{\circ} \mathrm{C}$ (Shelf life)

** Carboxymethyl cellulose LSD at 5\%, $P=0.80, T=1.28, S=1.39, P x T=1.79, \quad S x T=3.11, \quad S x P=1.96, P x S x T=4.39$

Chitosan-coated products showed significantly lower POD activity, probably as a result of delaying damaging of membrane and in response to low temperature of storage. Chitosan films decrease the content of Lipoxygenase (LOX) and Malondialdehyde (MAD) enzymes, so it is maintain the integrity membrane, preserve the skin and flesh color and barriers between PPO and POD enzymes from their phenolic substrates. On the other hand, observed inhibition of POD and PPO activities by chitosan films and improved postharvest shelf life of products (Zhang et al 2015). 
Statistical significant differences between coating treatments and packaging were noticed. Broccoli florets dipped in chitosan at $1 \%$ or $0.5 \%$ and packed in non-PPPb reduced the POD activity as compared with other treatments, while the highest active POD was recorded by uncoated florets and packed in micro-PPPb.

The interaction among coating treatments, packaging and at the end of storage period was significant. After 20 days at $0^{\circ} \mathrm{C}$ plus 2 days at $10^{\circ} \mathrm{C}$, broccoli florets dipped in chitosan at $1 \%$ and then packed in non-PPPb showed the less active POD, while untreated control packed in micro-PPPb gave the highest active POD.

Zhuang et al (1995) reported that yellowing of florets is correlated with peroxidation of lipids (Malondialdehyde) which caused degradation of cell products. The florets of broccoli produce ethylene which degrades lipids and make senescence. Thus, low temperature may inhibit lipid degradation of cells and inhibiting the action of ethylene.

\section{CONCLUSION}

Broccoli florets dipped in chitosan $1 \%$ and then packed in non-PPPb was the most effective treatment in maintaining quality attributes and gave florets with good appearance after 20 days at $0^{\circ} \mathrm{C}$ plus 2 days at $10^{\circ} \mathrm{C}$ (shelf life) without decay.

\section{REFERENCE}

Ansorena M.R.N., Marcovich E. and Roura S.I. 2011. Impact of edible coatings and mild heat shocks on quality of minimally processed broccoli. Postharvest Biology and Technology, 59, 53-63.

AOAC. 1990. Quality of Official Analytical Chemists, Washington DC. USA.

Balouchi Z., Peyvast G.A., Ghasemnezhad M. and Saadatian M. 2011. Changes of antioxidant compounds of broccoli (Brassica oleracea L. var.Italoca) during storage at low and high temperatures.2011. South Western J. Hortic. Biol. Environ., 2(2), 193-212.

Baltacig C., Veliog S. and Karacabey E. 2011. Changes in total phenolic and flavonoid contents of rowanberry fruit during postharvest storage. Food Quality 34, 278-283.

Bastrash S., Makhlouf J., Castaigne F. and Willemot C. 1993. Optimal controlled atmosphere conditions for storage of broccoli florets. J. of Food Science. 58(2), 338-341.
Cantwell M., Nie X. and Hong G. 2009. Impact of storage conditions on grape tomato quality. $6^{\text {th }}$ ISHS Postharvest Symposium, Antalya, Turkey, 8 p.

Charles F.F. and Rij R.E. 1991. Temperature of broccoli florets at time of packaging influences package. HortScience. 26, 1301-1303.

Devlieghere F., Vermeulen A. and Debevere J. 2004. Chitosan: antimicrobial activity, interactions with food components and applicability as a coating on fruit and vegetables. Food Microbiology, 21, 703-714.

Durango A., Soares N. and Andrade N. 2006. Microbiological evaluation of an edible antimicrobial coating on minimally processed carrots. Food Control, 17, 336-341.

Dutta P.K., Tripathi S., Methrota G.K. and Dutta J. 2009. Perspectives for chitosan based antimicrobial films in food application. Food Chemistry, 114, 1173-1182.

Fan X. and Mattheis J.P. 2000. Yellowing of broccoli in storage is reduced by 1 -Methylcyclopropene. Hort. Science, 35, 885-887.

Forney C.F. and Rij R.E. 1991. Temperature of broccoli florets at time of packaging influences package atmosphere and quality. Hort. Science, 26, 1301-1303.

Forney C.F., Mattheis J.P. and Austin R.K. 1991. Volatile compound produced by broccoli under anaerobic conditions. J. Agreic. Food Chemistry, 39(12), 2257-2259.

Funamoto Y., Yamauchi N., Shigenaga T. and Shigyo M. 2002. Effects of heat treatment on chlorophyll degrading enzymes in stored broccoli (Brassica oleracea. L.). Postharvest Biology and Technology 24, 163-170.

González-Aguilar G., Valenzuela-Soto E., Lizardi-Mendoza J., Goycoolea F., Martínez-Téllez M. and Villegas-Ochoa M. 2009. Effect of chitosan coating in preventing deterioration and preserving the quality of fresh-cut papaya 'Maradol'. J. Sci. of Food \& Agric., 89, 15-23.

Gu H., Wang J., Zhao Z., Sheng X., Yu H. and Huang W. 2015. Characterization of the appearance, health-promoting compounds, and antioxidant capacity of the florets of the loose-curd cauliflower. Int. J. of Food Properties 18(2), 392-402.

Haffez M.M. 2016. Effect of postharvest treatments on quality and storability of fresh cut cantaloupe. Ph.D. Thesis, Fac. Agric., Ain Shams Univ., Cairo, Egypt, 138 p. 
Hansen M., Olsen C.E., Poll L. and Cantwell M.I. 1993. Volatile constituents and sensory quality of cooked broccoli florets after aerobic and anaerobic storage. Postharvest. 92, 105-111.

Hattori K., Abe E., Yoshida T. and Cuculo J.A. 2004. New solvents for cellulose II ethylenediamine/thiocyanate salt system. Polym. J. 36(2), 123-130.

Jacobsson A., Nielsen T., Sjöholm I. and Wendin K. 2004. Influence of packaging material and storage condition on the sensory quality of broccoli. Food Quality and Preference. 15, 301310.

Jiang A.L., Tian S.P. and Xu Y. 2002. Effect of controlled atmospheres with high $\mathrm{O}_{2}$ or high $\mathrm{CO}_{2}$ concentrations on postharvest physiology and storability of Napoleon sweet cherry. J. of Integrative Plant Biology 44(8), 925-930.

Jongsri P., Wangsomboondee T., Rojsitthisak P. and Seraypheap K. 2016. Effect of molecular weights of chitosan coating on postharvest quality and physicochemical characteristics of mango fruit. LWT - Food Science and Technology, 73, 28-36.

Kader A.A., Morris L.L. and Maxie E.C. 1973. Systems for scoring quality of harvested lettuce. Hort. Sci., 8, 408-409.

Kumar R. and Singh G. 2017. Changes in quality of broccoli storage under modified atmosphere packaging in polymeric films. Int. J. Curr. Microbial. App. Sci., 6(7), 924-937.

Lee J.Y., Park H.J., Lee C.Y. and Choi W.Y. 2003. Extending shelf life of minimally processed apples with edible coatings and antibrowning agents. Lebensmittel-Wissenschaft undTechnologie, 36, 323-329.

Lopez-Galvez G., Peiser G. and Nie X. 1997. Quality changes in packaged salad products during storage. Z Lebensm Unters Forfsch A. 205, 64-72.

Moreira M., Roura S. and Ponce A. 2011. Effectiveness of chitosan edible coatings to improve microbiological and sensory quality of fresh cut broccoli. LWT - Food Science and Technology, 44, 2335-2341.

Nath A., Bagchi B., Misra L.K. and Bidyut C.D. 2011. Changes in post-harvest phytochemical qualities of broccoli florets during ambient and refrigerated storage. Food Chemistry 127, 1510-1514.
Nath A., Bagchi B., Misra L.K. and Deka B.C. 2011. Changes in post-harvest phytochemical qualities of broccoli florets during ambient and refrigerated storage. Food Chemistry 127, 1510-1514.

Phuong N.T.H., Uchino T. and Tanaka F. 2018. Effect of packaging films on the quality of broccoli. J. Fac. Agric., Kyushu Univ., 63(2), 339346.

Queiroz C., Lopes M.M., Fialho E. and ValenteMesquita V.L. 2008. Polyphenol oxidase: characteristics and mechanisms of browning control. Food Rev. Int., 24, 361-375.

Raseetha S. and Nadirah S. 2018. Effect of different packaging materials on quality of fresh-cut broccoli and cauliflower at chilled temperature. Inter. Food Research J., 25(4), 1559-1565.

Raymond L.V., Zhang M. and Roknul Azam S.M. 2012. Effect of chitosan coating on physical and microbical characteristics of fresh-cut green peppers (Capsicum annum L.). Pakistan J. nutrition, 11(10), 806-811.

Risse R.A. and Miller W.R. 1986. Individual film wrapping of Florida cucumbers, eggplant, peppers and tomatoes for extending shelf life. J. Plastic Film and Sheeting, 2, 164-171.

Saad M.E. 2013. Effect of modified atmosphere storage on postharvest quality of some non-traditional vegetable crops. Ph.D. Thesis, Fac. Agric., Ain Shams Univ., Cairo, Egypt. 118 p.

SAS. 2006. Statisical Analysis System, SAS Users Guide: Statistical. SAS Institute Inc. Editors, Cary, NC.

Schlimme D.V. and Rooney M.L. 1994. Packaging of minimally processed fruits and vegetables. In R.C. Wiley (ED) Minimally Processed Refrigerated fruits \& Vegetables. Chapman \& Hall, New York, NY, pp. 135-182.

Serrano M., Martinez-Romero D., Guillén F., Castillo S. and Valero D. 2006. Maintenance of broccoli quality and functional prop-erties during cold storage as affected by modified atmosphere packaging. Postharvest Biology and Technology 39, 61-68.

Shehata S.A., Attia M.M., Mohamed M.El. and Abd-El-Rahman S.Z. 2011. Effect of pre and postharvest treatments on yield, head quality and storability broccoli florets during storage. Annals of Agric. Sci. Moshtohor. 49(3), 11-26. 
Shiri M.A., Bakhshi D., Ghasemnezhad M., Dadi M., Papachatzism A. and Kalorizou H. 2013. Chitosan coating improves the shelf life and postharvest quality of table grape (Vitis vinifera) cultivar Shahroudi. Turk J. Agric., 37, 148-156.

Singleton V.L., Orthofer R. and LamuelaRaventós R.M. 1999. Analysis of total phenols other oxidation substrates and antioxidants by means of Folin-Ciocalteu reagent. Methods in Enzymology, 299, 152-178.

Tzoumaki M.V., Biliaderis C.G. and Vasilakakis M. 2009. Impact of edible coatings and packaging on quality of white asparagus (Asparagus officinalis L.) during cold storage. Food Chemistry, 117, 55-63.

Vickers J.E., Grof C.P.L., Bonnett G.D., Jackson, P.A. and Morgan T.E. 2005. Effects of tissue culture biolistic transformation, and introduction of PPO and SPS gene constructs on performance of sugarcane clones in the field. Australian J. of Agric. Research, 56, 57-68.
Wills R.B.H., McGlasson W.B. Graham D., TH. L. and Hall E.G. 1989. Postharvest, an inteoduction to physiology and handling of fruits and vegetables. $3^{\text {rd }}$ end., New York, USA., Van Nostrand Reinhold 46 p.

Xing Y.G., Li X.H., Xu Q.L., Yung J., Lu Y.Q. and Tang Y. 2011. Effect of chitosan coating enriched with cinnamon oil on qualitative properties of sweet pepper (Capsicum annum, L.). Food Chem., 124, 1443-1450.

Zhang Z., Huber D.J., Qu H., Yun Z., Wang H., Huang Z. and Jiang Y. 2015. Enzymatic browning and antioxidant activities in harvested litchi fruit as influenced by apple polyphenols. Food Chem. 171, 191-199.

Zhuang H., Hidebrand D.F. and Barth M.M. 1995. Senescence of broccoli buds is related to changes in lipid peroxidation. J. Agric. Food Chem. 43, 2585-2591. 


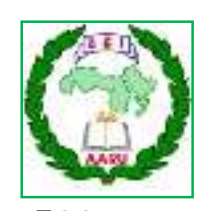

مجلة اتحاد الجامعات العربية للعلوم الزراعية، جامعة عين شمس، القاهرة، مصر مجلد(28)، عدد(2)، 562-547، 2020

Website: http://ajs.journals.ekb.eg

[40]

\author{
نعمة محمد حسين1" - ممدوح محمد فوزي عبد الله2 - أحمد أبو اليزيد² - \\ الويه البسيونى إبراهيم البسيوني

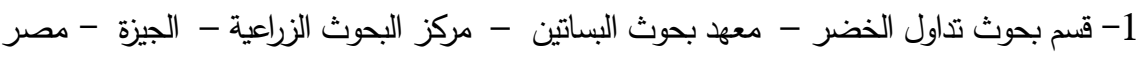 \\ 2- قسم البساتين - كلية الزراعة - جامعة عين شمس - صعب 68 - 68 - حدائق شبرا 11241 - القاهرة - مصرك
}

*Corresponding author: neama140@yahoo.com

Received 17 December, 2019

Accepted 10 July, 2020

المجزأه بزيادة فترات التخزين بينما حدث إنخفاض فى

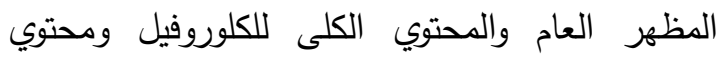
الفينولات الكليه. بالنسبه لتأثير مواد التعبئة أظهرت

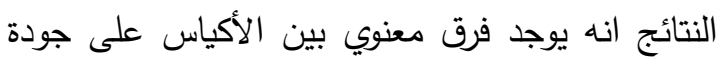

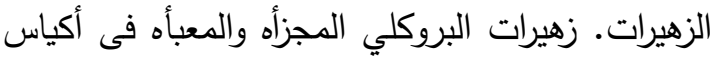

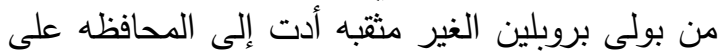

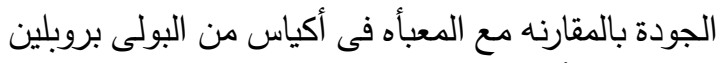

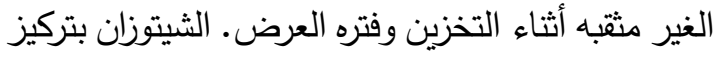

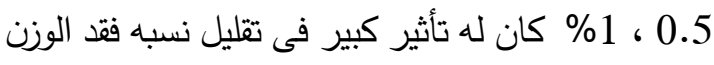

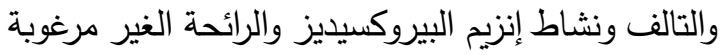

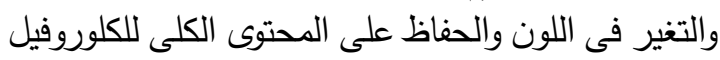

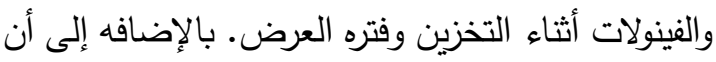

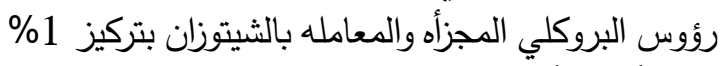

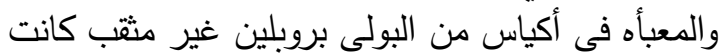

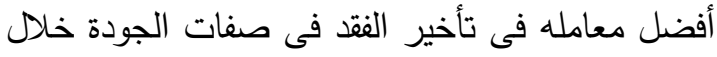

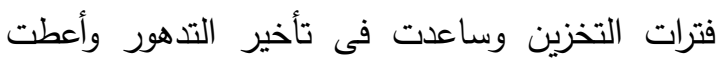
مظهر جيد بعد 20 يوم على صنفر المئوي بالإضافه إلى فئى 2 يوم على 10 درجه مئوية بدون تلفي

الكلمات المفتاحية: زهيرات البروكلي، الشيتوزان، كربوكسي ميثيل سيليلوز، مواد التعبئه، التخزين المبرد، لمبرد، فتره العرض علي الرف مبن ميل

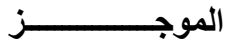

تم جمع رؤوس البروكلي هجين ساكورا فى مرحله النضج المناسب للتسويق من مزرعة خاصئ هاصه بالنوباريه

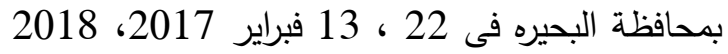

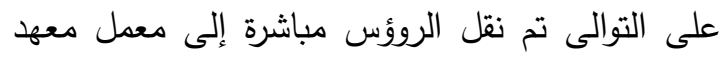
بحوث البساتين - مركز البحوث الزراعية. تأثير الأغشية

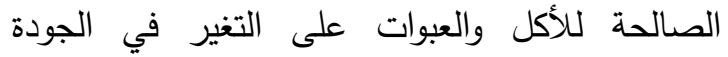

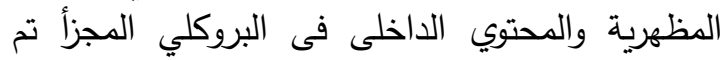
تقديرها عند التخزين على الصفر المئوي. تم شطف الصفائ البروكلي المجزأ إلى زهيرات بالماء المحتئ المتوي على المئ كلور

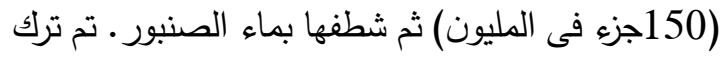

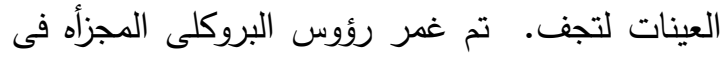

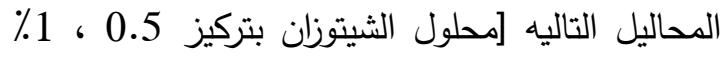

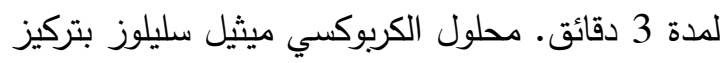
0.5، 1\% لمدة 3 دقائق بجانب الماء المقطر (المقارنة)] تم تجفيف جميع المعاملات السابقه ثم تعبئتها فى أكياس

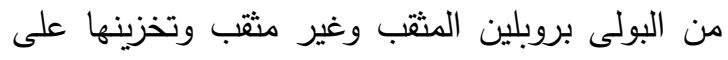

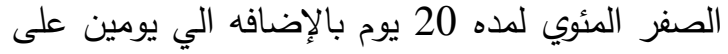

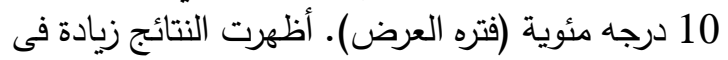

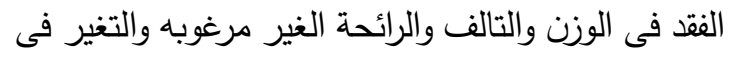

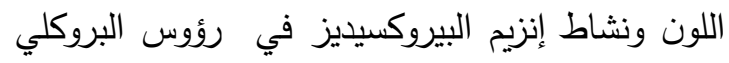

تحكيم: ا.د شادي محمد الشهاوي أ. أ.د أشرف مهدي مهي أد أدي أ. أ.د عبير فؤاد أحمد في 